Mironova L.I. ${ }^{1}$, Zhartayev E. M. ${ }^{2}$, Alekhin V.N. ${ }^{3}$

${ }^{1-3}$ Ural Federal University, Yekaterinburg, Russia

E-mail: ${ }^{1}$ mirmila@mail.ru, ${ }^{2}$ zhartaevem@gmail.com, ${ }^{3}$ referetsf@yandex.ru

\title{
MATHEMATICAL MODEL FOR DETERMINATION OF FORMATION PROFESSIONAL COMPETENCE LEVEL OF BACHELORS IN THE FIELD OF A CONSTRUCTION
}

Abstract. In the article competences of bachelors and areas of the Construction regulated Federal State educational standards of the higher education (FSES HE) are considered. Level approach for assessment of their formation is offered (low, medium, basic, high). The substantial essence of each of levels is provided. According to the educational standard professional competences are considered in the following areas: prospecting and design activities (P\&DA); production and technological and production management activity (PT\&PMA); experimental and research activities (ERA); assembly and adjustment and service and operational activities (AA\&SOA); business activity (BA). The mathematical model based on a method of standardization of ranks which allows to receive numerical intervals for assessment of level of formation of competence of this or that area is developed for each type of professional activity.

The algorithm of a mathematical model creation is considered. The procedure of reduction of rank estimates to a comparable form is called standardization of ranks and, in our case, will consist in the procedure of simple uniform stretching of shorter scales to the required length. For each attribute the current standardized rank is equal to a difference between the maximum and minimum appointed ranks of attribute, divided into quantity of empty cages. After holding a procedure of standardization of ranks function which behavior allows to define 4 numerical intervals which can be used for determination of level of formation of professional competences of bachelors of this or that field of construction is based.

Practical application of the developed mathematical model assumes automation of process of an assessment of level of formation of professional competence of this or that sphere of activity by means of realization in the form of the interactive program module and development of the special educational and methodical materials allowing to show to future bachelor-builder existence of practical experience in the studied spheres of activity.

Keywords: mathematical model, method of standardization of ranks, levels of formation of professional competence, estimative intervals.

\section{Миронова Л. И. ${ }^{1}$, Жартаев Е. М. ${ }^{2}$, Алехин В. Н. ${ }^{3}$}

1-3 Уральский федеральный университтет, Екатеринбург, Россия

E-mail: ${ }^{1}$ mirmila@mail.ru, ${ }^{2}$ zhartaevem@gmail.com, ${ }^{3}$ referetsf@yandex.ru

\section{МАТЕМАТИЧЕСКАЯ МОДЕЛЬ ДЛЯ ОПРЕДЕЛЕНИЯ УРОВНЯ СФОРМИРОВАННОСТИ ПРОФЕССИОНАЛЬНОЙ КОМПЕТЕНТНОСТИ БАКАЛАВРОВ В ОБЛАСТИ СТРОИТЕЛЬСТВА}

Аннотация. В статье рассмотрены компетенции бакалавров в области строительства, регламентированные Федеральным образовательным стандартом высшего образования. Предложен уровневый подход для оценки их сформированности (низкий, средний, базовый, высокий). Представлена содержательная сущность каждого из уровней. Согласно образовательному стандарту профессиональные компетенции рассмотрены в следующих областях: изыскательской и проектно-конструкторской деятельности (И и ПКД); производственно-технологической и производственно-управленческой деятельности (ПТ и ПУД); экспериментально-исследовательской деятельности (ЭИД); монтажно-наладочной и сервисно-эксплуатационной деятельности (МН и СЭД); предпринимательской деятельности (ПД). Для каждого вида профессиональной деятельности разработана математическая модель, основанная на методе стандартизации рангов, которая позволяет получить числовые интервалы для оценки уровня сформированности компетентности в той или иной области.

Рассмотрен алгоритм построения математической модели.

Процедура приведения ранговых оценок к сопоставимому виду называется стандартизацией рангов и в нашем случае будет представлять собой простое равномерное растяжение более коротких шкал до требуемой длины. Для каждого атрибута текущий стандартизованный ранг равен разности между максимальным и минимальным назначенными рангами атрибута, деленной на количество пустых клеток. После проведения процедуры стандартизации рангов строится функция, поведение которой позволяет определить 4 числовых интервала, которые могут быть использованы для определения уровня сформированности профессиональных компетенций бакалавров в той или иной области строительства.

Практическое применение разработанной математической модели предполагает автоматизацию процесса оценки уровня сформированности профессиональной компетентности в той или иной области деятельности посредством ре- 
ализации в виде интерактивного программного модуля и разработку специальных учебно-методических материалов, позволяющих будущему бакалавру-строителю продемонстрировать наличие практического опыта в исследуемых областях деятельности.

Ключевые слова: математическая модель, метод стандартизации рангов, уровни сформированности профессиональной компетентности, оценочные интервалы.

(C) Mironova L. I., Zhartayev E. M., Alekhin V. N., 2017

The competency structure of the bachelor studying in the direction 08.03.01 the Construction according to Federal state educational standard of the higher education FSES HE [13], includes competences of three types: common cultural, all-professional and professional. The greatest interest in the conditions of the market relations and the increased requirements of employers to level of training of university graduates is represented by professional competences.

Professional competences according to FSES HE in the direction of Construction are considered in areas [13]:

- prospecting and design activities (P\&DA);

- production and technological and production management activity (PT\& PMA);

- experimental and research activities (E\&RA);

- assembly and adjustment and service and operational activities (AA\&SOA);

- business activity (BA).

Creation of mathematical model for determination of level of formation of professional competence of this or that subject domain is based on the theoretical provisions published in work [5, 6, 7].

According to the competence-based approach in education $[3,11]$ assuming identification of theoretical and practical aspects of educational process on the basis of formation of set of knowledge, abilities and experience of different types of activity, the student has to be able to show the abilities in practice.

Level approach to an assessment of assimilation of a training material is based on B. Blum [2] taxonomy offered in 1956 and assuming presence of $6 \mathrm{lev}-$ els of cogitative abilities of the student: knowledge, understanding, application, analysis, synthesis, assessment. B. Blum's ideas have gained development in pedagogical researches of Lebedev O.E., Maximova V.N., Simonov V.P., Skatkin M.N., Teslenko V.I., etc. The greatest distribution in domestic pedagogical science was gained by Bespalko's approach Accusative [1] which has offered 4 levels of assimilation of a training material: low - student's (recognition), medium - algorithmic (the solution of standard tasks), basic - heuristic (the action choice), high - creative (action search).

Extrapolating level approach to formation the professional competences according to Bespalko V.P. [1] we will consider low, medium, basic and high the level of their formation.
The low level of formation of professional competences at the bachelor is characterized by experience on distinction, recognition of professional objects, concepts, terms at repeated perception of earlier studied material, on performance of actions with them, but "with the hint", retelling and copying of educational information.

The medium level of formation of professional competences at the bachelor is characterized by experience on independent reproduction and application of professional information in the standard situations considered earlier in training activity.

The basic level of formation of professional competences at the bachelor is characterized by experience on use of the acquired professional knowledge and abilities in atypical situations, to obtaining new knowledge by action of a sample.

The high level of formation of professional competences at the bachelor is characterized by experience of action in unforeseen situations and creation of new algorithms, rules, actions, that is subjectively new information.

In the course of examination of level of formation of professional competences of bachelors of construction area, according to Novikova T. G. researches [8], we will construct mathematical model for definition of numerical intervals for their assessment. Object of examination - process of formation of professional competences of bachelors of construction area, means of examination - mathematical model, the procedure of examination - joint activity of skilled experts (experts), an examination product - the expert opinion, after coordination by the criteria offered for examination.

As attributes of process $[4,9,12]$ of formation of professional competences (PC) we will consider the regulated FSES HE competence in construction, and as signs of these attributes we will consider extents of manifestation of these competences at the bachelor.

Determination of level of formation of professional competences of the bachelor in prospecting and design activity

Let's consider area of prospecting and design activity (P\&DA) bachelors. Requirements of FSES HE and their detailed specification are submitted in the left extreme column of Table 1. 


\section{The regulated FSES HE the list of professional competences of the bachelor in the Construction direction in the field of prospecting and design activity}

\begin{tabular}{|c|c|c|}
\hline $\begin{array}{l}\text { The list of the competences regulated by } \\
\text { FSES HE in the field of P\&DA }\end{array}$ & The graduate shows: & $\begin{array}{l}\text { Appointed } \\
\text { ranks }\end{array}$ \\
\hline \multirow{8}{*}{$\begin{array}{l}\text { PC-1: knows the regulatory base in the } \\
\text { field of engineering researches, the prin- } \\
\text { ciples of design of buildings, constructions, } \\
\text { engineering systems and the equipment, } \\
\text { planning and building of the inhabited } \\
\text { places }\end{array}$} & $\begin{array}{l}\text { Knowledge of the regulatory base in the field of engineering re- } \\
\text { searches at a low level }\end{array}$ & 1 \\
\hline & At the medium level & 2 \\
\hline & At the basic level & 3 \\
\hline & At the high level & 4 \\
\hline & $\begin{array}{l}\text { Knowledge of the principles of design of buildings, constructions, } \\
\text { engineering systems and the equipment, planning and building of } \\
\text { the inhabited places at a low level }\end{array}$ & 5 \\
\hline & At the medium level & 6 \\
\hline & At the basic level & 7 \\
\hline & At the high level & 8 \\
\hline \multirow{12}{*}{$\begin{array}{l}\text { PC-1: owns methods of carrying out engi- } \\
\text { neering researches, technology of design of } \\
\text { details and designs according to S with use } \\
\text { universal and specialized by PCS and SAD }\end{array}$} & $\begin{array}{l}\text { Ability to own methods of carrying out engineering researches at } \\
\text { a low level }\end{array}$ & 1 \\
\hline & At the medium level & 2 \\
\hline & At the basic level & 3 \\
\hline & At the high level & 4 \\
\hline & $\begin{array}{l}\text { Ability to own technology of design of details and designs } \\
\text { according to the specification }(\mathrm{S})\end{array}$ & 5 \\
\hline & At the medium level & 6 \\
\hline & At the basic level & 7 \\
\hline & At the high level & 8 \\
\hline & $\begin{array}{l}\text { Skills of use of the universal and specialized program computer } \\
\text { systems (PCS) and systems of automation of design (SAD) at a } \\
\text { low level }\end{array}$ & 9 \\
\hline & At the medium level & 10 \\
\hline & At the basic level & 11 \\
\hline & At the high level & 12 \\
\hline \multirow[t]{4}{*}{$\begin{array}{l}\text { PC-2: it is capable to carry out the prelimi- } \\
\text { nary feasibility study on design decisions }\end{array}$} & $\begin{array}{l}\text { Ability to carry out the preliminary feasibility study on design } \\
\text { decisions at a low level }\end{array}$ & 1 \\
\hline & At the medium level & 2 \\
\hline & At the basic level & 3 \\
\hline & At the high level & 4 \\
\hline
\end{tabular}




\begin{tabular}{|c|c|c|}
\hline $\begin{array}{l}\text { The list of the competences regulated by } \\
\text { FSES HE in the field of P\&DA }\end{array}$ & The graduate shows: & $\begin{array}{l}\text { Appointed } \\
\text { ranks }\end{array}$ \\
\hline \multirow{8}{*}{$\begin{array}{l}\text { PC-2: it is capable to develop project and } \\
\text { working documentation }\end{array}$} & Ability to develop the project documentation at a low level & 1 \\
\hline & At the medium level & 2 \\
\hline & At the basic level & 3 \\
\hline & At the high level & 4 \\
\hline & Ability to develop working documentation at a low level & 5 \\
\hline & At the medium level & 6 \\
\hline & At the basic level & 7 \\
\hline & At the high level & 8 \\
\hline \multirow{4}{*}{$\begin{array}{l}\text { PC-3: it is capable to make out the finished } \\
\text { construction work }\end{array}$} & Ability to make out the finished construction work at a low level & 1 \\
\hline & At the medium level & 2 \\
\hline & At the basic level & 3 \\
\hline & At the high level & 4 \\
\hline \multirow{8}{*}{$\begin{array}{l}\text { PC-3: it is capable to control compliance } \\
\text { of the developed projects and technical } \\
\text { documentation of standards, specifications } \\
\text { and other normative documents }\end{array}$} & $\begin{array}{l}\text { Ability to control compliance of the developed projects and tech- } \\
\text { nical documentation to the specification }(\mathrm{S}) \text { at a low level }\end{array}$ & 1 \\
\hline & At the medium level & 2 \\
\hline & At the basic level & 3 \\
\hline & At the high level & 4 \\
\hline & $\begin{array}{l}\text { Ability to control compliance of the developed projects and } \\
\text { technical documentation to standards, specifications and other } \\
\text { normative documents at a low level }\end{array}$ & 5 \\
\hline & At the medium level & 6 \\
\hline & At the basic level & 7 \\
\hline & At the high level & 8 \\
\hline
\end{tabular}


STEP 1. Let's describe pedagogical process of formation of competences of bachelors of area in the area P\&DA by means of attributes and signs corresponding to them. Results of this step are presented on medium a column of Table 1.

STEP 2. Let's appoint to signs of attributes of the studied process ranks. Results of this step are presented in the right extreme column in Table 1. Let's write out values of the appointed ranks in Table 2.

Value of the appointed ranks to attributes process of formation of competences of the bachelor of area P\&DA

\begin{tabular}{|c|c|c|c|c|c|c|c|c|c|c|c|c|}
\hline $\begin{array}{c}\text { No. } \\
\text { attribute } \\
\text { P\&DA }\end{array}$ & \multicolumn{10}{|c|}{ Appointed ranks } \\
\hline 1 (PC-1) & 1 & 2 & 3 & 4 & 5 & 6 & 7 & 8 & & & & \\
\hline 2 (PC-1) & 1 & 2 & 3 & 4 & 5 & 6 & 7 & 8 & 9 & 10 & 11 & 12 \\
\hline 3 (PC-2) & 1 & 2 & 3 & 4 & & & & & & & & \\
\hline 4 (PC-2) & 1 & 2 & 3 & 4 & 5 & 6 & 7 & 8 & & & & \\
\hline 5 (PC-3) & 1 & 2 & 3 & 4 & & & & & & & & \\
\hline 6 (PC-3) & 1 & 2 & 3 & 4 & 5 & 6 & 7 & 8 & & & & \\
\hline
\end{tabular}

In order that it was possible to compare signs of attributes among themselves, it is necessary to carry out the procedure of standardization of ranks which consists in stretching of shorter attributes to the longest $[5,10]$.

STEP 3. Let's make the procedure of standardization of ranks which results are presented in Table 3.
As a result of carrying out standardization of ranks we have received the table valued function and presented in Table 4.

Table 4

Table valued function for determining level of formation of professional competences of bachelors of $\mathrm{BI}$ in the area P\&DA

\begin{tabular}{|c|c|c|c|c|c|c|c|c|c|c|c|c|}
\hline$X$ & 1 & 2 & 3 & 4 & 5 & 6 & 7 & 8 & 9 & 10 & 11 & 12 \\
\hline$Y$ & 1 & 0.78 & 0.95 & 1.12 & 1.28 & 1.45 & 1.62 & 1.78 & 1.95 & 2.12 & 2.28 & 7.33 \\
\hline
\end{tabular}

STEP 4. Let's construct the schedule of this function on a piece $[1,12]$ (Fig. 1).

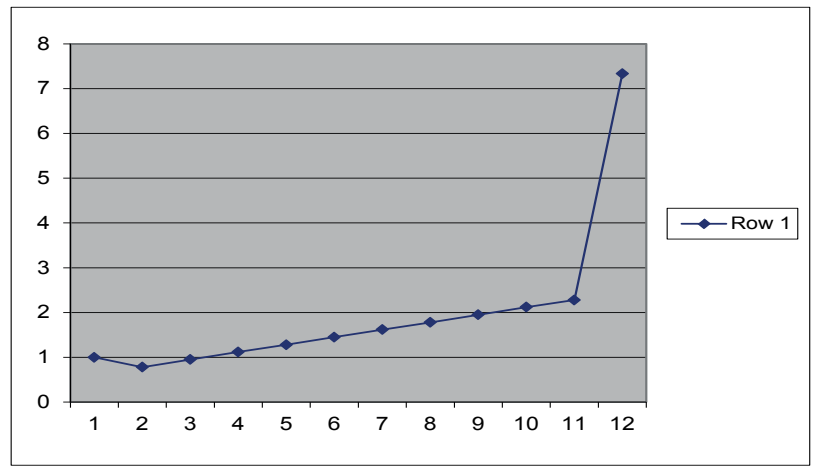

Fig. 1. The schedule of change of medium values of ranks when determining level of formation of professional competences of bachelors in the area P\&DA at bachelors of BI

In Fig. 1 follows from the schedule that the interval $[1,12]$ breaks border points 2,3 and 11 into 4 areas. The result of recalculation of border points for definition of estimated intervals is presented in Table 5.

Table 3

Values of the standardized ranks on signs of attributes of process of formation of competences of the bachelor of $B I$ of area P\&DA

\begin{tabular}{|c|c|c|c|c|c|c|c|c|c|c|c|c|}
\hline $\begin{array}{c}\text { No. } \\
\text { attribute } \\
\text { P\&DA }\end{array}$ & \multicolumn{10}{|c|}{ Standardized ranks } \\
\hline 1 & 1 & 0.7 & 0.7 & 0.7 & 0.7 & 0.7 & 0.7 & 0.7 & 0.7 & 0.7 & 0.7 & 8 \\
\hline 2 & 1 & 2 & 3 & 4 & 5 & 6 & 7 & 8 & 9 & 10 & 11 & 12 \\
\hline 3 & 1 & 0.3 & 0.3 & 0.3 & 0.3 & 0.3 & 0.3 & 0.3 & 0.3 & 0.3 & 0.3 & 4 \\
\hline 4 & 1 & 0.7 & 0.7 & 0.7 & 0.7 & 0.7 & 0.7 & 0.7 & 0.7 & 0.7 & 0.7 & 8 \\
\hline 5 & 1 & 0.3 & 0.3 & 0.3 & 0.3 & 0.3 & 0.3 & 0.3 & 0.3 & 0.3 & 0.3 & 4 \\
\hline 6 & 1 & 0.7 & 0.7 & 0.7 & 0.7 & 0.7 & 0.7 & 0.7 & 0.7 & 0.7 & 0.7 & 8 \\
\hline Av.val. & 1 & 0.78 & 0.95 & 1.12 & 1.28 & 1.45 & 1.62 & 1.78 & 1.95 & 2.12 & 2.28 & 7.33 \\
\hline
\end{tabular}


Table 5

Results of recalculation values of border points in estimated intervals when determining level of formation of competences of bachelors of $\mathrm{BI}$ in the area P\&DA

\begin{tabular}{|c|c|c|c|}
\hline $\begin{array}{c}\text { Values } \\
\text { boundary } \\
\text { ranks }\end{array}$ & $\begin{array}{c}\text { \% of values } \\
\text { boundary ranks } \\
\text { from the maxi- } \\
\text { mum quantity of } \\
\text { ranks (12) }\end{array}$ & $\begin{array}{c}\text { Sum of ranks, } \\
\text { corresponding } \\
\text { to border points } \\
\text { from the sum of } \\
\text { the maximum } \\
\text { ranks (44) }\end{array}$ & $\begin{array}{c}\text { Estimated } \\
\text { Interval }\end{array}$ \\
\hline 2 & 17 & 7 & $\Sigma \leqslant 7$ \\
\hline 3 & 25 & 11 & $8 \leqslant \Sigma \leqslant 11$ \\
\hline 11 & 92 & 40 & $12 \leqslant \Sigma \leqslant 40$ \\
\hline
\end{tabular}

Now it is possible to formulate final estimated intervals for determination of level of formation of competences of bachelors of $\mathrm{BI}$ in prospecting and design activity which are presented in Table 6 .
Table 6

Estimated intervals for determination of level formation of professional competences of bachelors of $\mathrm{BI}$ in the area P\&DA

\begin{tabular}{|c|l|l|}
\hline No. & Sum of ranks & \multicolumn{1}{|c|}{ Recommendations of the expert } \\
\hline 1 & $\begin{array}{l}\text { The sum of } \\
\text { ranks is less } \\
\text { than 7 points }\end{array}$ & $\begin{array}{l}\text { In the area P\&DA professional } \\
\text { competences are created at a low } \\
\text { level }\end{array}$ \\
\hline 2 & $\begin{array}{l}\text { The sum of } \\
\text { ranks is from } \\
8 \text { to 11 points }\end{array}$ & $\begin{array}{l}\text { In the area P\&DA professional } \\
\text { competences are created at the } \\
\text { medium level }\end{array}$ \\
\hline 3 & $\begin{array}{l}\text { The sum of } \\
\text { ranks is from } \\
12 \text { to 40 points }\end{array}$ & $\begin{array}{l}\text { In the area P\&DA professional } \\
\text { competences are created at the basic } \\
\text { level }\end{array}$ \\
\hline 4 & $\begin{array}{l}\text { The sum of } \\
\text { ranks is more } \\
40 \text { points }\end{array}$ & $\begin{array}{l}\text { In the area P\&DA professional } \\
\text { competences are created at the high } \\
\text { level }\end{array}$ \\
\hline
\end{tabular}

The definition of the competence level of bachelor of $\mathrm{BI}$ in the field of production technology and production management activity (PT\& PMA)

FSES HE requirements and detailed specification of competences of bachelors of BI in the field of PT\&PM are presented in Table 7.

Table 7

\section{Regulated list of competences of the bachelor of BI in the field of production technology and production management activity}

\begin{tabular}{|c|c|c|}
\hline $\begin{array}{l}\text { The list of the competences regu- } \\
\text { lated by FSES HE in the field of } \\
\text { PT\&PM }\end{array}$ & The graduate shows: & $\begin{array}{l}\text { Appointed } \\
\text { Ranks }\end{array}$ \\
\hline \multirow{4}{*}{$\begin{array}{l}\text { PC-4: ability to participate in the } \\
\text { design and finding of objects of } \\
\text { professional activity }\end{array}$} & $\begin{array}{l}\text { The ability to participate in the design and finding of objects of } \\
\text { professional activity at a low level }\end{array}$ & 1 \\
\hline & At the medium level & 2 \\
\hline & At the basic level & 3 \\
\hline & At the high level & 4 \\
\hline \multirow{12}{*}{$\begin{array}{l}\text { PC-5: knows the requirements of } \\
\text { the occupational health, safety and } \\
\text { environmental protection when } \\
\text { performing construction, repairs } \\
\text { and reconstruction of construction } \\
\text { objects }\end{array}$} & Knowledge of health and safety requirements at a low level & 1 \\
\hline & At the medium level & 2 \\
\hline & At the basic level & 3 \\
\hline & At the high level & 4 \\
\hline & Knowledge of the requirements of health and safety at a low level & 5 \\
\hline & At the medium level & 6 \\
\hline & At the basic level & 7 \\
\hline & At the high level & 8 \\
\hline & $\begin{array}{l}\text { Knowledge of the requirements of environmental protection at the low } \\
\text { level }\end{array}$ & 9 \\
\hline & At the medium level & 10 \\
\hline & At the basic level & 11 \\
\hline & At the high level & 12 \\
\hline
\end{tabular}




\begin{tabular}{|c|c|c|}
\hline $\begin{array}{l}\text { The list of the competences regu- } \\
\text { lated by FSES HE in the field of } \\
\text { PT\&PM }\end{array}$ & The graduate shows: & $\begin{array}{l}\text { Appointed } \\
\text { Ranks }\end{array}$ \\
\hline \multirow{4}{*}{$\begin{array}{l}\text { PC-6: ability } \\
\text { implement and organize technical } \\
\text { operation of buildings and con- } \\
\text { structions of objects of housing and } \\
\text { communal services (HCS) }\end{array}$} & $\begin{array}{l}\text { The ability to implement and organize the technical maintenance of the } \\
\text { buildings and facilities of HCS at a low level }\end{array}$ & 1 \\
\hline & At the medium level & 2 \\
\hline & At the basic level & 3 \\
\hline & At the high level & 4 \\
\hline \multirow{4}{*}{$\begin{array}{l}\text { PC-6: ability to ensure the } \\
\text { reliability, safety and efficiency of } \\
\text { the buildings and facilities of HCS }\end{array}$} & $\begin{array}{l}\text { The ability to provide reliability, safety and efficiency of buildings and } \\
\text { construction of housing facilities at the low level }\end{array}$ & 5 \\
\hline & At the medium level & 6 \\
\hline & At the basic level & 7 \\
\hline & At the high level & 8 \\
\hline \multirow{4}{*}{$\begin{array}{l}\text { PC-7: ability to analyse technical } \\
\text { efficiency of production units and } \\
\text { to develop measures for its improve- } \\
\text { ment }\end{array}$} & $\begin{array}{l}\text { The ability to analyze the technical efficiency of production units and to } \\
\text { develop measures for its improvement at a low level }\end{array}$ & 1 \\
\hline & At the medium level & 2 \\
\hline & At the basic level & 3 \\
\hline & At the high level & 4 \\
\hline \multirow{4}{*}{$\begin{array}{l}\text { PC-7: ability to analyse and eco- } \\
\text { nomic efficiency of a production } \\
\text { unit and to develop measures } \\
\text { for its improvement }\end{array}$} & $\begin{array}{l}\text { The ability to analyze and efficiency of a production unit and to develop } \\
\text { measures for its improvement at the low level }\end{array}$ & 5 \\
\hline & At the medium level & 6 \\
\hline & At the basic level & 7 \\
\hline & At the high level & 8 \\
\hline \multirow{8}{*}{$\begin{array}{l}\text { PC-8: owns the technology, meth- } \\
\text { ods, debugging and development } \\
\text { of technological processes of con- } \\
\text { struction, operation, maintenance } \\
\text { of buildings, engineering systems }\end{array}$} & $\begin{array}{l}\text { The technology skills, methods, debugging and development of techno- } \\
\text { logical processes of building production at a low level }\end{array}$ & 1 \\
\hline & At the medium level & 2 \\
\hline & At the basic level & 3 \\
\hline & At the high level & 4 \\
\hline & $\begin{array}{l}\text { The technology skills, methods, debugging and development of } \\
\text { technological processes of operation, maintenance of buildings, } \\
\text { engineering systems at a low level }\end{array}$ & 5 \\
\hline & At the medium level & 6 \\
\hline & At the basic level & 7 \\
\hline & At the high level & 8 \\
\hline \multirow{4}{*}{$\begin{array}{l}\text { PC-8: owns the technology, } \\
\text { methods, debugging and } \\
\text { development of technological } \\
\text { processes of production of building } \\
\text { materials, products and structures, } \\
\text { machinery and equipment }\end{array}$} & $\begin{array}{l}\text { The technology skills, methods, debugging and development of techno- } \\
\text { logical processes of production of building materials at a low level }\end{array}$ & 9 \\
\hline & At the medium level & 10 \\
\hline & At the basic level & 11 \\
\hline & At the high level & 12 \\
\hline
\end{tabular}




\begin{tabular}{|c|c|c|}
\hline $\begin{array}{l}\text { The list of the competences regu- } \\
\text { lated by FSES HE in the field of } \\
\text { PT\&PM }\end{array}$ & The graduate shows: & $\begin{array}{l}\text { Appointed } \\
\text { Ranks }\end{array}$ \\
\hline & $\begin{array}{l}\text { The technology skills, methods, debugging and development of } \\
\text { technological processes of manufacture of building products and } \\
\text { structures at a low level }\end{array}$ & 13 \\
\hline & At the medium level & 14 \\
\hline & At the basic level & 15 \\
\hline & At the high level & 16 \\
\hline & $\begin{array}{l}\text { The technology skills, methods, debugging and development of } \\
\text { technological processes of production of building machinery and } \\
\text { equipment at the low level }\end{array}$ & 17 \\
\hline & At the medium level & 18 \\
\hline & At the basic level & 19 \\
\hline & At the high level & 20 \\
\hline \multirow{4}{*}{$\begin{array}{l}\text { PC-9: ability to prepare documen- } \\
\text { tation for quality management and } \\
\text { standard methods of quality control } \\
\text { of technological processes at pro- } \\
\text { duction sites }\end{array}$} & $\begin{array}{l}\text { The ability to prepare documentation for quality management and stan- } \\
\text { dard methods of quality control of technological processes at produc- } \\
\text { tion sites at the low level }\end{array}$ & 1 \\
\hline & At the medium level & 2 \\
\hline & At the basic level & 3 \\
\hline & At the high level & 4 \\
\hline \multirow{4}{*}{$\begin{array}{l}\text { PC-9: ability } \\
\text { to organize jobs, provide techni- } \\
\text { cal equipment, accommodation } \\
\text { and maintenance of technological } \\
\text { equipment }\end{array}$} & $\begin{array}{l}\text { The ability to organize jobs, provide technical equipment, accommoda- } \\
\text { tion and maintenance of technological equipment at a low level }\end{array}$ & 5 \\
\hline & At the medium level & 6 \\
\hline & At the basic level & 7 \\
\hline & At the high level & 8 \\
\hline \multirow{4}{*}{$\begin{array}{l}\text { PC-9: ability to exercise control } \\
\text { of observance of technological } \\
\text { discipline, labor protection and } \\
\text { environmental safety }\end{array}$} & $\begin{array}{l}\text { The ability to exercise control of observance of technological discipline, } \\
\text { labor protection and environmental safety at a low level }\end{array}$ & 9 \\
\hline & At the medium level & 10 \\
\hline & At the basic level & 11 \\
\hline & At the high level & 12 \\
\hline \multirow{4}{*}{$\begin{array}{l}\text { PC-10: knows the organizational- } \\
\text { legal foundations of business and } \\
\text { management in the sphere of con- } \\
\text { struction and housing }\end{array}$} & $\begin{array}{l}\text { Knowledge of the organizational-legal foundations of business and } \\
\text { management in the sphere of construction and housing at a low level }\end{array}$ & 1 \\
\hline & At the medium level & 2 \\
\hline & At the basic level & 3 \\
\hline & At the high level & 4 \\
\hline \multirow[t]{4}{*}{$\begin{array}{l}\text { PC-10: knows the basics of work } \\
\text { planning personnel and payroll }\end{array}$} & $\begin{array}{l}\text { Knowledge of the principles of planning personnel and payroll at a low } \\
\text { level }\end{array}$ & 5 \\
\hline & At the medium level & 6 \\
\hline & At the basic level & 7 \\
\hline & At the high level & 8 \\
\hline
\end{tabular}




\begin{tabular}{|c|c|c|}
\hline $\begin{array}{l}\text { The list of the competences regu- } \\
\text { lated by FSES HE in the field of } \\
\text { PT\&PM }\end{array}$ & The graduate shows: & $\begin{array}{l}\text { Appointed } \\
\text { Ranks }\end{array}$ \\
\hline \multirow{4}{*}{$\begin{array}{l}\text { PC-11: a mastery of methods of im- } \\
\text { plementation of innovative ideas, } \\
\text { the organization of production and } \\
\text { effective management of people }\end{array}$} & $\begin{array}{l}\text { Possession of methods of implementation of innovative ideas, the or- } \\
\text { ganization of production and effective management of people at a low } \\
\text { level }\end{array}$ & 1 \\
\hline & At the medium level & 2 \\
\hline & At the basic level & 3 \\
\hline & At the high level & 4 \\
\hline \multirow{4}{*}{$\begin{array}{l}\text { PC-11: a mastery of methods of } \\
\text { preparation of documentation for } \\
\text { creation of system of quality man- } \\
\text { agement of the production unit }\end{array}$} & $\begin{array}{l}\text { Possession of methods of preparation of documentation for creation of } \\
\text { system of quality management of the production unit at a low } \\
\text { level }\end{array}$ & 5 \\
\hline & At the medium level & 6 \\
\hline & At the basic level & 7 \\
\hline & At the high level & 8 \\
\hline \multirow{4}{*}{$\begin{array}{l}\text { PC-12: ability to develop } \\
\text { operational work plans of primary } \\
\text { production units }\end{array}$} & $\begin{array}{l}\text { The ability to develop operational work plans of primary production } \\
\text { units at a low level }\end{array}$ & 1 \\
\hline & At the medium level & 2 \\
\hline & At the basic level & 3 \\
\hline & At the high level & 4 \\
\hline \multirow{4}{*}{$\begin{array}{l}\text { PC-12: ability to conduct analysis } \\
\text { of the costs and results of produc- } \\
\text { tion activities }\end{array}$} & $\begin{array}{l}\text { The ability to conduct cost analysis and manufacturing activities at a } \\
\text { low level }\end{array}$ & 5 \\
\hline & At the medium level & 6 \\
\hline & At the basic level & 7 \\
\hline & At the high level & 8 \\
\hline \multirow{4}{*}{$\begin{array}{l}\text { PC-12: ability to prepare technical } \\
\text { documentation and the established } \\
\text { reporting on approved forms }\end{array}$} & $\begin{array}{l}\text { Ability to prepare technical documentation and the established report- } \\
\text { ing on approved forms at a low level }\end{array}$ & 9 \\
\hline & At the medium level & 10 \\
\hline & At the basic level & 11 \\
\hline & At the high level & 12 \\
\hline
\end{tabular}


STEP 1. We describe the pedagogical process of formation of competences of bachelors of BI in the field of production technology and production management activity by attributes and their corresponding characteristics. The results of this step are presented in the left and middle columns of the Table 7.

STEP 2. Assign the signs of the attributes of the process under study the ranks. The results of this step are presented in the rightmost column in Table 7. Write down the values assigned to the grades in Table 8 .

STEP 3. Will produce the procedure of standardization of ranks, the results of which are presented in Table 9.

As a result of the standardization of ranks we now have a function that given table, and are presented in Table 10.

Values assigned grade attributes process of formation of professional competence of bachelors of BI in the field of production technology and production management activity

\begin{tabular}{|c|c|c|c|c|c|c|c|c|c|c|c|c|c|c|c|c|c|c|c|c|}
\hline $\begin{array}{c}\text { No. } \\
\text { attribute }\end{array}$ & \multicolumn{20}{|c|}{ Appointed ranks } \\
\hline $1(\mathrm{PC}-4)$ & 1 & 2 & 3 & 4 & & & & & & & & & & & & & & & & \\
\hline $2(\mathrm{PC}-5)$ & 1 & 2 & 3 & 4 & 5 & 6 & 7 & 8 & 9 & 10 & 11 & 12 & & & & & & & & \\
\hline $3(\mathrm{PC}-6)$ & 1 & 2 & 3 & 4 & 5 & 6 & 7 & 8 & & & & & & & & & & & & \\
\hline $4(\mathrm{PC}-7)$ & 1 & 2 & 3 & 4 & 5 & 6 & 7 & 8 & & & & & & & & & & & & \\
\hline $5(\mathrm{PC}-8)$ & 1 & 2 & 3 & 4 & 5 & 6 & 7 & 8 & 9 & 10 & 11 & 12 & 13 & 14 & 15 & 16 & 17 & 18 & 19 & 20 \\
\hline $6(\mathrm{PC}-9)$ & 1 & 2 & 3 & 4 & 5 & 6 & 7 & 8 & 9 & 10 & 11 & 12 & & & & & & & & \\
\hline 7 (PC-10) & 1 & 2 & 3 & 4 & 5 & 6 & 7 & 8 & & & & & & & & & & & & \\
\hline $8(\mathrm{PC}-11)$ & 1 & 2 & 3 & 4 & 5 & 6 & 7 & 8 & & & & & & & & & & & & \\
\hline 9 (PC-12) & 1 & 2 & 3 & 4 & 5 & 6 & 7 & 8 & 9 & 10 & 11 & 12 & & & & & & & & \\
\hline
\end{tabular}

Table 9

Values of the standardized ranks on the grounds of attributes of the process of formation of competences of bachelors of BI PT\&PMA

\begin{tabular}{|c|c|c|c|c|c|c|c|c|c|c|c|c|c|c|c|c|c|c|c|c|}
\hline \multirow{2}{*}{$\begin{array}{c}\begin{array}{c}\text { No. } \\
\text { attribute } \\
\text { PT\&PM }\end{array} \\
1\end{array}$} & \multirow{2}{*}{$\frac{\xi}{\sum}$} & \multicolumn{18}{|c|}{ Standardized ranks } & \multirow{2}{*}{ 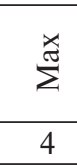 } \\
\hline & & 0.2 & 0.2 & 0.2 & 0.2 & 0.2 & 0.2 & 0.2 & 0.2 & 0.2 & 0.2 & 0.2 & 0.2 & 0.2 & 0.2 & 0.2 & 0.2 & 0.2 & 0.2 & \\
\hline 2 & 1 & 0.6 & 0.6 & 0.6 & 0.6 & 0.6 & 0.6 & 0.6 & 0.6 & 0.6 & 0.6 & 0.6 & 0.6 & 0.6 & 0.6 & 0.6 & 0.6 & 0.6 & 0.6 & 12 \\
\hline 3 & 1 & 0.4 & 0.4 & 0.4 & 0.4 & 0.4 & 0.4 & 0.4 & 0.4 & 0.4 & 0.4 & 0.4 & 0.4 & 0.4 & 0.4 & 0.4 & 0.4 & 0.4 & 0.4 & 8 \\
\hline 4 & 1 & 0.4 & 0.4 & 0.4 & 0.4 & 0.4 & 0.4 & 0.4 & 0.4 & 0.4 & 0.4 & 0.4 & 0.4 & 0.4 & 0.4 & 0.4 & 0.4 & 0.4 & 0.4 & 8 \\
\hline 5 & 1 & 2 & 3 & 4 & 5 & 6 & 7 & 8 & 9 & 10 & 11 & 12 & 13 & 14 & 15 & 16 & 17 & 18 & 19 & 20 \\
\hline 6 & 1 & 0.6 & 0.6 & 0.6 & 0.6 & 0.6 & 0.6 & 0.6 & 0.6 & 0.6 & 0.6 & 0.6 & 0.6 & 0.6 & 0.6 & 0.6 & 0.6 & 0.6 & 0.6 & 12 \\
\hline 7 & 1 & 0.4 & 0.4 & 0.4 & 0.4 & 0.4 & 0.4 & 0.4 & 0.4 & 0.4 & 0.4 & 0.4 & 0.4 & 0.4 & 0.4 & 0.4 & 0.4 & 0.4 & \begin{tabular}{|l|}
0.4 \\
\end{tabular} & 8 \\
\hline 8 & 1 & 0.4 & 0.4 & 0.4 & 0.4 & 0.4 & 0.4 & 0.4 & 0.4 & 0.4 & 0.4 & 0.4 & 0.4 & 0.4 & 0.4 & 0.4 & 0.4 & 0.4 & 0.4 & 8 \\
\hline 9 & 1 & 0.6 & 0.6 & 0.6 & 0.6 & 0.6 & 0.6 & 0.6 & 0.6 & 0.6 & 0.6 & 0.6 & 0.6 & 0.6 & 0.6 & 0.6 & 0.6 & 0.6 & 0.6 & 12 \\
\hline Av.val. & 1 & 0.62 & 0.73 & 0.84 & 0.95 & \begin{tabular}{|l|l|} 
\\
\end{tabular} & 1.2 & 1.3 & 1.4 & 1.5 & 1.6 & 1.7 & 1.8 & 1.9 & 2.0 & 2.2 & 2.3 & 2.4 & 2.5 & 10.2 \\
\hline
\end{tabular}

Table 10

Table valued function for determining level of formation of professional competences of bachelors of BI in the area PT\&PMA

\begin{tabular}{|c|c|c|c|c|c|c|c|c|c|c|c|c|c|c|c|c|c|c|c|c|}
\hline$X$ & 1 & 2 & 3 & 4 & 5 & 6 & 7 & 8 & 9 & 10 & 11 & 12 & 13 & 14 & 15 & 16 & 17 & 18 & 19 & 20 \\
\hline$Y$ & 1 & 0.62 & 0.73 & 0.84 & 0.95 & 1.1 & 1.2 & 1.3 & 1.4 & 1.5 & 1.6 & 1.7 & 1.8 & 1.9 & 2.0 & 2.2 & 2.3 & 2.4 & 2.5 & 10.2 \\
\hline
\end{tabular}


STEP 4. Let's plot this function on the interval [1, 20] (Fig. 2).

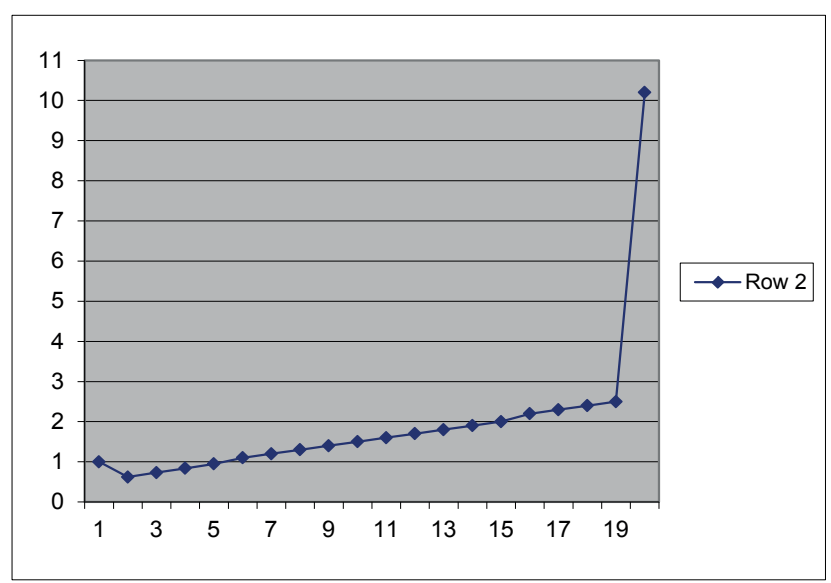

Fig. 2. The schedule of change of medium values of ranks when determining level of formation of competences of bachelors of BI in in the field PT\&PMA

In Fig. 2 follows from the schedule that the interval $[1,20]$ breaks border points 2,5 and 19 into 4 areas. The result of recalculation of border points for definition of estimated intervals is presented in Table 11.

Table 11

Results of recalculation values of border points in estimated intervals when determining level of formation of competences of bachelors of $B I$ in the field of PT\&PMA

\begin{tabular}{|c|c|c|c|}
\hline $\begin{array}{c}\text { Values } \\
\text { boundary } \\
\text { ranks }\end{array}$ & $\begin{array}{c}\text { \% of values } \\
\text { boundary } \\
\text { ranks } \\
\text { from the maxi- } \\
\text { mum quantity } \\
\text { of ranks (20) }\end{array}$ & $\begin{array}{c}\text { Sum of ranks, } \\
\text { corresponding } \\
\text { to border points } \\
\text { from the sum of } \\
\text { the maximum } \\
\text { ranks }(92)\end{array}$ & $\begin{array}{c}\text { Estimated } \\
\text { Interval }\end{array}$ \\
\hline 2 & 10 & 9 & $1 \leqslant \Sigma \leqslant 9$ \\
\hline
\end{tabular}

\begin{tabular}{|c|c|c|c|}
\hline $\begin{array}{c}\text { Values } \\
\text { boundary } \\
\text { ranks }\end{array}$ & $\begin{array}{c}\text { \% of values } \\
\text { boundary } \\
\text { ranks } \\
\text { from the maxi- } \\
\text { mum quantity } \\
\text { of ranks (20) }\end{array}$ & $\begin{array}{c}\text { Sum of ranks, } \\
\text { corresponding } \\
\text { to border points } \\
\text { from the sum of } \\
\text { the maximum } \\
\text { ranks (92) }\end{array}$ & $\begin{array}{c}\text { Estimated } \\
\text { Interval }\end{array}$ \\
\hline 5 & 25 & 23 & $10 \leqslant \Sigma \leqslant 23$ \\
\hline 19 & 95 & 81 & $24 \leqslant \Sigma \leqslant 81$ \\
\hline
\end{tabular}

Now it is possible to formulate final estimated intervals for determination of level of formation of competences of bachelors of $\mathrm{BI}$ in production and technological and production management activity which are presented in Table 12.

Table 12

Estimated intervals for determination of level formation of professional competences of bachelors of BI in the field of PT\&PMA

\begin{tabular}{|c|c|c|}
\hline No. & Sum of ranks & $\begin{array}{c}\text { Recommendations of the } \\
\text { expert }\end{array}$ \\
\hline 1 & $\begin{array}{c}\text { The sum of ranks is } \\
\text { less than 9 points }\end{array}$ & $\begin{array}{c}\text { In the area PT\&DPM } \\
\text { professional competences are } \\
\text { created at a low level }\end{array}$ \\
\hline 2 & $\begin{array}{c}\text { The sum of ranks is } \\
\text { from 10 to 23 points }\end{array}$ & $\begin{array}{c}\text { In the area PT\&PMA } \\
\text { professional competences are } \\
\text { created at the medium level }\end{array}$ \\
\hline 3 & $\begin{array}{c}\text { The sum of ranks is } \\
\text { from } 24 \text { to } 81 \text { points }\end{array}$ & $\begin{array}{c}\text { In the area PT\&PMA } \\
\text { professional competences are } \\
\text { created at the basic level }\end{array}$ \\
\hline 4 & $\begin{array}{c}\text { The sum of ranks is } \\
\text { more } 82 \text { points }\end{array}$ & $\begin{array}{c}\text { In the area PT\&PMA } \\
\text { professional competences are } \\
\text { created at the high level }\end{array}$ \\
\hline
\end{tabular}

Determination of level of formation of competences of the bachelor of STI in experimental and research activity

Requirements of FSES HE and their detailed specification for bachelors of BI in the field of the experimental and research activity (E\&RA) are presented in Table 13.

Table 13

\section{The regulated FSES HE the list of competences of the bachelor of BI in experimental and research activity}

\begin{tabular}{|l|l|c|}
\hline \multicolumn{1}{|c|}{$\begin{array}{c}\text { The list of the competences regulated by } \\
\text { FSES HE in the field of E\&PA }\end{array}$} & \multicolumn{1}{|c|}{ The graduate shows: } & \multicolumn{1}{c|}{$\begin{array}{c}\text { Appointed } \\
\text { ranks }\end{array}$} \\
\hline $\begin{array}{l}\text { PC-13: knows scientific and technical in- } \\
\text { formation, domestic and foreign experi- } \\
\text { ment on an activity profile }\end{array}$ & $\begin{array}{l}\text { Knowledge of scientific and technical information on an activ- } \\
\text { ity profile at a low level }\end{array}$ & 1 \\
\cline { 2 - 3 } & At the medium level & 2 \\
\cline { 2 - 3 } & At the basic level & 4 \\
\cline { 2 - 3 } & At the high level & 5 \\
\cline { 2 - 3 } & $\begin{array}{l}\text { Knowledge of domestic and foreign experiment on an activity } \\
\text { profile at a low level }\end{array}$ & 6 \\
\cline { 2 - 3 } & At the medium level & 7 \\
\cline { 2 - 3 } & At the basic level & 1 \\
\cline { 2 - 3 } $\begin{array}{l}\text { PC-14: possession of methods and means } \\
\text { of physical and computer modeling with } \\
\text { use of universal and specialized program } \\
\text { computer systems }\end{array}$ & $\begin{array}{l}\text { Possession of methods and means of physical and computer } \\
\text { modeling with use of universal and specialized program com- } \\
\text { puter systems at a low level }\end{array}$ & 2 \\
\cline { 2 - 3 } & At the medium level & 3 \\
\cline { 2 - 3 } & At the basic level & 4 \\
\cline { 2 - 3 } & At the high level & 2 \\
\hline
\end{tabular}




\begin{tabular}{|c|c|c|}
\hline $\begin{array}{l}\text { The list of the competences regulated by } \\
\text { FSES HE in the field of E\&PA }\end{array}$ & The graduate shows: & $\begin{array}{l}\text { Appointed } \\
\text { ranks }\end{array}$ \\
\hline \multirow{4}{*}{$\begin{array}{l}\text { PC-14: possession of methods and means } \\
\text { of physical and computer modeling with } \\
\text { use of systems of automation of design } \\
\text { (SAD) }\end{array}$} & $\begin{array}{l}\text { Possession of methods and means of physical and computer } \\
\text { modeling with use of SAD at a low level }\end{array}$ & 1 \\
\hline & At the medium level & 2 \\
\hline & At the basic level & 3 \\
\hline & At the high level & 4 \\
\hline \multirow{4}{*}{$\begin{array}{l}\text { PC-14: possession of methods and means } \\
\text { of physical and computer modeling with } \\
\text { use of standard packages of automation of } \\
\text { researches }\end{array}$} & $\begin{array}{l}\text { Possession of methods and means of physical and computer } \\
\text { modeling with use of standard packages of automation of re- } \\
\text { searches at a low level }\end{array}$ & 5 \\
\hline & At the medium level & 6 \\
\hline & At the basic level & 7 \\
\hline & At the high level & 8 \\
\hline \multirow[t]{4}{*}{$\begin{array}{l}\text { PC-14: possession of test methods of } \\
\text { building constructions and products }\end{array}$} & $\begin{array}{l}\text { Possession of test methods of building constructions and prod- } \\
\text { ucts at a low level }\end{array}$ & 1 \\
\hline & At the medium level & 2 \\
\hline & At the basic level & 3 \\
\hline & At the high level & 4 \\
\hline \multirow{4}{*}{$\begin{array}{l}\text { PC-14: possession of methods of statement } \\
\text { and carrying out experiments by the set } \\
\text { techniques }\end{array}$} & $\begin{array}{l}\text { Possession of methods of statement and carrying out experi- } \\
\text { ments by the set techniques at a low level }\end{array}$ & 5 \\
\hline & At the medium level & 6 \\
\hline & At the basic level & 7 \\
\hline & At the high level & 8 \\
\hline \multirow{4}{*}{$\begin{array}{l}\text { PC-15: it is capable to make reports on the } \\
\text { performed works }\end{array}$} & Ability to make reports on the performed works at a low level & 1 \\
\hline & At the medium level & 2 \\
\hline & At the basic level & 3 \\
\hline & At the high level & 4 \\
\hline \multirow[t]{4}{*}{$\begin{array}{l}\text { PC-15: it is capable to participate in intro- } \\
\text { duction of results of researches }\end{array}$} & $\begin{array}{l}\text { Ability to participate in introduction of results of researches at } \\
\text { a low level }\end{array}$ & 5 \\
\hline & At the medium level & 6 \\
\hline & At the basic level & 7 \\
\hline & At the high level & 8 \\
\hline \multirow{4}{*}{$\begin{array}{l}\text { PC-15: it is capable to participate in prac- } \\
\text { tical developments }\end{array}$} & Ability to participate in practical developments at a low level & 9 \\
\hline & At the medium level & 10 \\
\hline & At the basic level & 11 \\
\hline & At the high level & 12 \\
\hline
\end{tabular}

STEP 1. Let's describe pedagogical process of formation of competences of bachelors of BI in experimental and research activity by means of attributes and signs corresponding to them. Results of this step are presented in the left and medium columns of Table 13.

STEP 2. Let's appoint to signs of attributes of the studied process ranks. Results of this step are present- ed in the right extreme column in Table 13. Let's write out values of the appointed ranks in Table 14.

STEP 3. Let's make the procedure of standardization of ranks which results are presented in Table 15. As a result of carrying out standardization of ranks we have received the function set tablichno (Table 16).

STEP 4. Let's construct the schedule of this function on a piece [1, 12] (Fig. 3).

Table 14

Values of the appointed ranks to attributes process of formation of competences of the bachelor of STI in the field of experimental and research activity

\begin{tabular}{|c|c|c|c|c|c|c|c|c|c|c|c|c|}
\hline $\begin{array}{l}\text { No. } \\
\text { attribute }\end{array}$ & \multicolumn{12}{|c|}{ Appointed ranks } \\
\hline $1 \mathrm{PC}-13$ & 1 & 2 & 3 & 4 & 5 & 6 & 7 & 8 & & & & \\
\hline $2 \mathrm{PC}-14$ & 1 & 2 & 3 & 4 & & & & & & & & \\
\hline 3 PC-14 & 1 & 2 & 3 & 4 & 5 & 6 & 7 & 8 & & & & \\
\hline $4 \mathrm{PC}-14$ & 1 & 2 & 3 & 4 & 5 & 6 & 7 & 8 & & & & \\
\hline $5 \mathrm{PC}-15$ & 1 & 2 & 3 & 4 & 5 & 6 & 7 & 8 & 9 & 10 & 11 & 12 \\
\hline
\end{tabular}


Values of the standardized ranks on signs of attributes of process of formation of competences of the bachelor of $\mathrm{BI}$ in the field of experimental and research activity

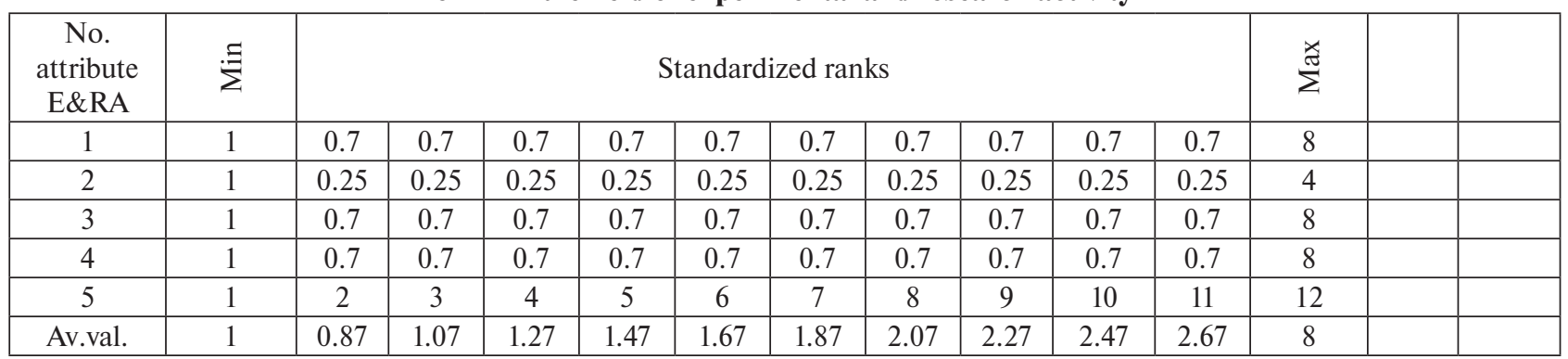

Table 16

Table valued function for determining level of formation of professional competences of bachelors of BI in the area E\&RA

\begin{tabular}{|c|c|c|c|c|c|c|c|c|c|c|c|c|}
\hline$X$ & 1 & 2 & 3 & 4 & 5 & 6 & 7 & 8 & 9 & 10 & 11 & 12 \\
\hline$Y$ & 1 & 0.87 & 1.07 & 1.27 & 1.47 & 1.67 & 1.87 & 2.07 & 2.27 & 2.47 & 2.67 & 8 \\
\hline
\end{tabular}

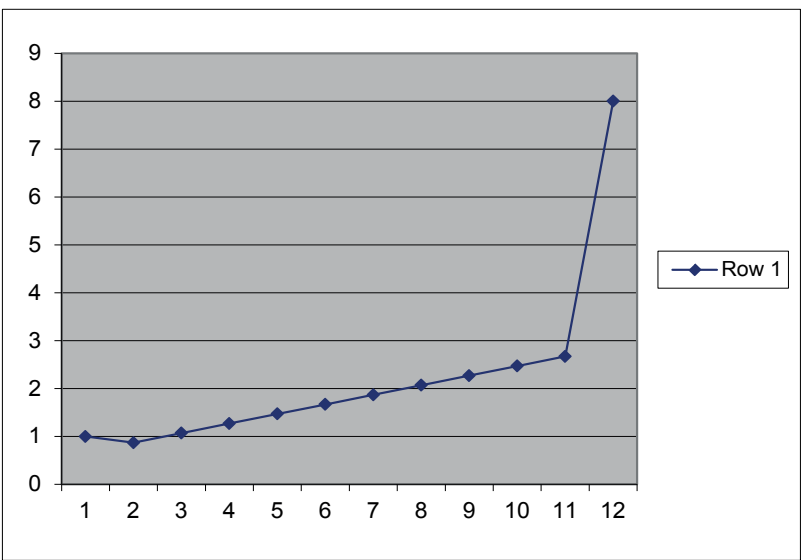

Fig. 3. The schedule of change of medium values of ranks when determining level of formation of competences of bachelors of BI in the field of experimental and research activity

In Fig. 3 follows from the schedule that the interval $[1,12]$ breaks border points 2, 3 and 11 into 4 areas. The result of recalculation of border points for definition of estimated intervals is presented in Table 17.

Results of recalculation of values of border points in estimated intervals when determining level of formation of competences of bachelors of $\mathrm{BI}$ in experimental and research activity

\begin{tabular}{|c|c|c|c|}
\hline $\begin{array}{c}\text { Values } \\
\text { bound- } \\
\text { ary } \\
\text { ranks }\end{array}$ & $\begin{array}{c}\text { \% of values } \\
\text { boundary ranks } \\
\text { from the maxi- } \\
\text { mum quantity of } \\
\text { ranks (12) }\end{array}$ & $\begin{array}{c}\text { Sum of ranks, } \\
\text { corresponding } \\
\text { to border points } \\
\text { from the sum of } \\
\text { the maximum } \\
\text { ranks (40) }\end{array}$ & $\begin{array}{c}\text { Estimated } \\
\text { Interval }\end{array}$ \\
\hline 2 & 17 & 7 & $1 \leqslant \Sigma \leqslant 7$ \\
\hline 3 & 25 & 10 & $8 \leqslant \Sigma \leqslant 10$ \\
\hline
\end{tabular}

\begin{tabular}{|c|c|c|c|}
\hline $\begin{array}{c}\text { Values } \\
\text { bound- } \\
\text { ary } \\
\text { ranks }\end{array}$ & $\begin{array}{c}\text { \% of values } \\
\text { boundary ranks } \\
\text { from the maxi- } \\
\text { mum quantity of } \\
\text { ranks (12) }\end{array}$ & $\begin{array}{c}\text { Sum of ranks, } \\
\text { corresponding } \\
\text { to border points } \\
\text { from the sum of } \\
\text { the maximum } \\
\text { ranks }(40)\end{array}$ & $\begin{array}{c}\text { Estimated } \\
\text { Interval }\end{array}$ \\
\hline 11 & 92 & 37 & $11 \leqslant \Sigma \leqslant 37$ \\
\hline
\end{tabular}

Now it is possible to formulate estimated intervals for determination of level of formation of competences of bachelors of STI in experimental and research activity which are presented in Table 18.

Table 18

Levels of formation of competences of bachelors of BI in experimental and research activity

\begin{tabular}{|c|c|c|}
\hline No. & Sum of ranks & Recommendations of the expert \\
\hline 1 & $\begin{array}{c}\text { The sum of ranks is } \\
\text { less than 8 points }\end{array}$ & $\begin{array}{c}\text { In the area E\&RA professional } \\
\text { competences are created at a low } \\
\text { level }\end{array}$ \\
\hline 2 & $\begin{array}{c}\text { The sum of ranks is } \\
\text { from 9 to 10 points }\end{array}$ & $\begin{array}{c}\text { In the area E\&RA professional } \\
\text { competences are created at the } \\
\text { medium level }\end{array}$ \\
\hline 3 & $\begin{array}{c}\text { The sum of ranks is } \\
\text { from } 11 \text { to } 37 \text { points }\end{array}$ & $\begin{array}{c}\text { In the area E\&RA professional } \\
\text { competences are created at the } \\
\text { basic level }\end{array}$ \\
\hline 4 & $\begin{array}{c}\text { The sum of ranks is } \\
\text { more 37 points }\end{array}$ & $\begin{array}{c}\text { In the area E\&RA professional } \\
\text { competences are created at the } \\
\text { high level }\end{array}$ \\
\hline
\end{tabular}

Determination of level of formation of competences of the bachelor of BI in assembly and adjustment and service and operational activity

The requirements of FSES HE for bachelor of BI and detailed details of them in the field of assembly and adjustment and service and operational activities (AA \& SOA) are presented in Table 19. 


\section{The list of professional competences of the bachelor of BI In the field of assembly and adjustment} and service and operational activities

\begin{tabular}{|c|c|c|}
\hline $\begin{array}{l}\text { The list of the competences regu- } \\
\text { lated by FSES HE in the field of } \\
\text { AA\&SOA }\end{array}$ & The graduate shows: & $\begin{array}{l}\text { Appointed } \\
\text { Ranks }\end{array}$ \\
\hline \multirow{8}{*}{$\begin{array}{l}\text { PC-16: knowledge of the rules } \\
\text { and technology of installation, } \\
\text { commissioning, testing and } \\
\text { commissioning and operation of } \\
\text { structures, engineering systems } \\
\text { and equipment of construction } \\
\text { sites, objects of housing and com- } \\
\text { munal services }\end{array}$} & $\begin{array}{l}\text { Knowledge of the rules and technology of installation of structures, engineer- } \\
\text { ing systems and equipment of construction sites, housing and utilities objects } \\
\text { at a low level }\end{array}$ & 1 \\
\hline & At the medium level & 2 \\
\hline & At the basic level & 3 \\
\hline & At the high level & 4 \\
\hline & $\begin{array}{l}\text { Knowledge of the rules and technologies for adjusting structures, engineering } \\
\text { systems and equipment of construction sites, housing and communal services } \\
\text { at a low level }\end{array}$ & 5 \\
\hline & At the medium level & 6 \\
\hline & At the basic level & 7 \\
\hline & At the high level & 8 \\
\hline \multirow{4}{*}{$\begin{array}{l}\text { PC-16: knowledge of the rules } \\
\text { for accepting samples of products } \\
\text { manufactured by the enterprise }\end{array}$} & $\begin{array}{l}\text { Knowing the rules for accepting samples of products produced by an enter- } \\
\text { prise at a low level }\end{array}$ & 1 \\
\hline & At the medium level & 2 \\
\hline & \begin{tabular}{|l|} 
At the basic level \\
\end{tabular} & 3 \\
\hline & At the high level & 4 \\
\hline \multirow[t]{4}{*}{$\begin{array}{l}\text { PC-17: knowledge of methods of } \\
\text { testing equipment and tools }\end{array}$} & $\begin{array}{l}\text { Possession of methods of experimental testing of equipment and technologi- } \\
\text { cal support at a low level }\end{array}$ & 1 \\
\hline & At the medium level & 2 \\
\hline & At the basic level & 3 \\
\hline & At the high level & 4 \\
\hline \multirow{4}{*}{$\begin{array}{l}\text { PC-18: knowledge of methods } \\
\text { for monitoring and assessing the } \\
\text { technical condition and residual } \\
\text { life of construction sites and utili- } \\
\text { ties, construction and housing- } \\
\text { communal equipment }\end{array}$} & $\begin{array}{l}\text { Possession of methods for monitoring and assessing the technical condition } \\
\text { and residual life of construction sites and housing-communal equipment at a } \\
\text { low level }\end{array}$ & 1 \\
\hline & At the medium level & 2 \\
\hline & \begin{tabular}{|l|} 
At the basic level \\
\end{tabular} & 3 \\
\hline & At the high level & 4 \\
\hline \multirow{4}{*}{$\begin{array}{l}\text { PC18: knowledge of methods } \\
\text { for monitoring and assessing the } \\
\text { technical condition of construc- } \\
\text { tion and housing - communal } \\
\text { equipment }\end{array}$} & $\begin{array}{l}\text { Possession of methods for monitoring and assessing the technical condition } \\
\text { of construction and housing - communal equipment at a low level }\end{array}$ & 5 \\
\hline & At the medium level & 6 \\
\hline & At the basic level & 7 \\
\hline & At the high level & 8 \\
\hline \multirow{4}{*}{$\begin{array}{l}\text { PC-19: knows the basics of the } \\
\text { organization of preventive exami- } \\
\text { nations, repairs, acceptance and } \\
\text { development of the introduced } \\
\text { equipment }\end{array}$} & $\begin{array}{l}\text { Ability to organize preventive inspections, repairs, acceptance and develop- } \\
\text { ment of the introduced equipment at a low level }\end{array}$ & 1 \\
\hline & At the medium level & 2 \\
\hline & At the basic level & 3 \\
\hline & At the high level & 4 \\
\hline \multirow{4}{*}{$\begin{array}{l}\text { PC-19: knows the basics of mak- } \\
\text { ing requests for equipment and } \\
\text { spare parts }\end{array}$} & $\begin{array}{l}\text { Knowing the basics of making requests for equipment and spare parts at a low } \\
\text { level }\end{array}$ & 5 \\
\hline & At the medium level & 6 \\
\hline & At the basic level & 7 \\
\hline & At the high level & 8 \\
\hline \multirow{4}{*}{$\begin{array}{l}\text { PC-19: is able to prepare techni- } \\
\text { cal documentation and instruc- } \\
\text { tions for operation and repair of } \\
\text { equipment, engineering systems }\end{array}$} & $\begin{array}{l}\text { Ability to prepare technical documentation and instructions for operation and } \\
\text { repair of equipment, engineering systems at a low level }\end{array}$ & 9 \\
\hline & At the medium level & 10 \\
\hline & At the basic level & 11 \\
\hline & At the high level & 12 \\
\hline
\end{tabular}


The list of the competences regulated by FSES HE in the field of AA\&SOA

PC-20: knows the basics of organization and planning of technical operation of buildings and structures, housing and utilities objects in order to ensure reliability, economy and safety of their operation

STEP 1. We describe the pedagogical process of forming the competencies of BI bachelors in the field of assembly and adjustment and service and operational activities with the help of attributes and their corresponding characteristics. The results of this step are presented in the left and middle columns of Table 19.

STEP 2. Assign attributes of the attributes of the process being studied to the ranks. The results of this step are shown in the rightmost column in Table 19.

Let us write down the values of the assigned ranks in Table 20.

Table 20

Values of assigned ranks to attributes process of formation of Bachelor's competences in BI in the field of assembly and adjustment and service and operational activities

\begin{tabular}{|c|c|c|c|c|c|c|c|c|c|c|c|c|}
\hline $\begin{array}{c}\text { No. } \\
\text { attribute } \\
\text { AA\&SOA }\end{array}$ & \multicolumn{10}{|c|}{ Appointed ranks } \\
\hline 1 ПК-16 & 1 & 2 & 3 & 4 & 5 & 6 & 7 & 8 & & & & \\
\hline 2 ПК-16 & 1 & 2 & 3 & 4 & & & & & & & & \\
\hline 3 ПК-17 & 1 & 2 & 3 & 4 & & & & & & & & \\
\hline 4 ПК-18 & 1 & 2 & 3 & 4 & 5 & 6 & 7 & 8 & & & & \\
\hline 5 ПК-19 & 1 & 2 & 3 & 4 & 5 & 6 & 7 & 8 & 9 & 10 & 11 & 12 \\
\hline 6 ПК-20 & 1 & 2 & 3 & 4 & & & & & & & & \\
\hline
\end{tabular}

STEP 3. We perform the procedure for standardizing the ranks, the results of which are presented in Table 21.

As a result of the standardization of ranks, we obtained a function, given in tabular form and presented in Table 22.
The graduate shows:

Appointed

Ranks

1

4

Table 22

Table valued function for determining level of formation of professional competences of bachelors of $\mathrm{BI}$ in the area AA\&SOA

\begin{tabular}{|c|c|c|c|c|c|c|c|c|c|c|c|c|}
\hline$X$ & 1 & 2 & 3 & 4 & 5 & 6 & 7 & 8 & 9 & 10 & 11 & 12 \\
\hline$Y$ & 1 & 0.72 & 0.88 & 1.05 & 1.22 & 1.38 & 1.55 & 1.72 & 1.88 & 2.05 & 2.22 & 6.67 \\
\hline
\end{tabular}

STEP 4. We will construct a graph of this function on the interval [1, 12] (Fig. 4).

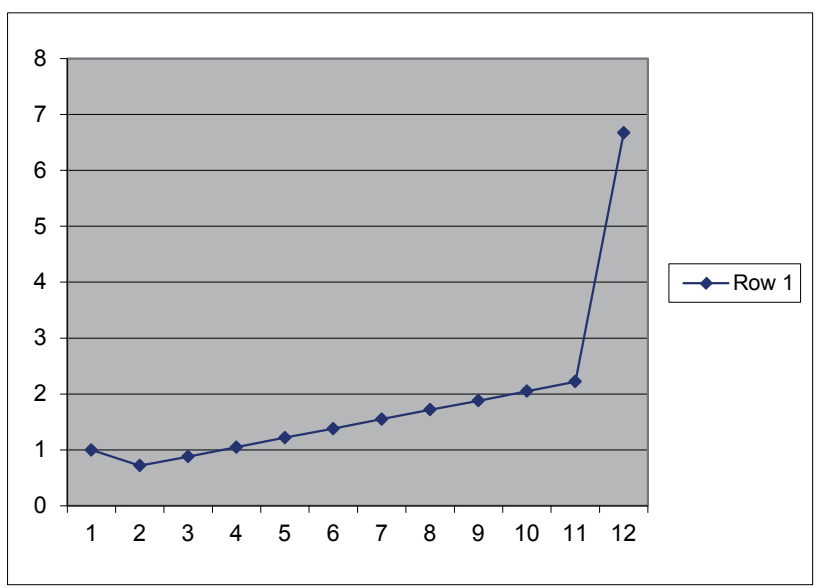

Fig. 4. The graph of the change in the average values of ranks in determining the level of competence of bachelor's degree in the field of assembly and adjustment and service and operational activities

From the graph in Fig. 4 it follows that the interval $[1,12]$ is divided by boundary points 2,4 and 11 into

Table 21

Values of Standardized ranks on the basis of attributes of the process of forming competences Bachelor of BI in the field of assembly and adjustment and service and operational activities

\begin{tabular}{|c|c|c|c|c|c|c|c|c|c|c|c|c|}
\hline $\begin{array}{c}\text { No. } \\
\text { attribute }\end{array}$ & $\Xi$ & \multicolumn{10}{|c|}{ Standardized ranks } & \multirow{2}{*}{ 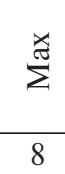 } \\
\hline 1 & 1 & 0.7 & 0.7 & 0.7 & 0.7 & 0.7 & 0.7 & 0.7 & 0.7 & 0.7 & 0.7 & \\
\hline 2 & 1 & 0.3 & 0.3 & 0.3 & 0.3 & 0.3 & 0.3 & 0.3 & 0.3 & 0.3 & 0.3 & 4 \\
\hline 3 & 1 & 0.3 & 0.3 & 0.3 & 0.3 & 0.3 & 0.3 & 0.3 & 0.3 & 0.3 & 0.3 & 4 \\
\hline 4 & 1 & 0.7 & 0.7 & 0.7 & 0.7 & 0.7 & 0.7 & 0.7 & 0.7 & 0.7 & 0.7 & 8 \\
\hline 5 & 1 & 2 & 3 & 4 & 5 & 6 & 7 & 8 & 9 & 10 & 11 & 12 \\
\hline 6 & 1 & 0.3 & 0.3 & 0.3 & 0.3 & 0.3 & 0.3 & 0.3 & 0.3 & 0.3 & 0.3 & 4 \\
\hline Av.val. & 1 & 0.72 & 0.88 & 1.05 & 1.22 & 1.38 & 1.55 & 1.72 & 1.88 & 2.05 & 2.22 & 6.67 \\
\hline
\end{tabular}


4 regions. The result of the recalculation of the boundary points to determine the estimated intervals is shown in Table 23.

Table 23

Translation results values of boundary points in the estimated intervals when determining the level of competence of bachelor's competences in BI in the field of assembly and adjustment and service and operational activities

\begin{tabular}{|c|c|c|c|}
\hline $\begin{array}{c}\text { Values } \\
\text { bound- } \\
\text { ary } \\
\text { ranks }\end{array}$ & $\begin{array}{c}\text { \% of values } \\
\text { boundary ranks } \\
\text { from the maxi- } \\
\text { mum quantity of } \\
\text { ranks (12) }\end{array}$ & $\begin{array}{c}\text { Sum of ranks, } \\
\text { corresponding } \\
\text { to border points } \\
\text { from the sum of } \\
\text { the maximum } \\
\text { ranks (40) }\end{array}$ & $\begin{array}{c}\text { Estimated } \\
\text { Interval }\end{array}$ \\
\hline 2 & 17 & 7 & $1 \leqslant \Sigma \leqslant 7$ \\
\hline 4 & 34 & 14 & $8 \leqslant \Sigma \leqslant 14$ \\
\hline 11 & 92 & 37 & $15 \leqslant \Sigma \leqslant 37$ \\
\hline
\end{tabular}

Now it is possible to formulate the final evaluation intervals for determining the level of the competence of the bachelors of the BI in the field of assembly and adjustment and service and operational activities, which are presented in Table 24.
Table 24

Formation levels professional competences of bachelors of BI in the field of assembly and adjustment and service and operational activities

\begin{tabular}{|c|c|c|}
\hline No. & Sum of ranks & $\begin{array}{c}\text { Recommendations of the } \\
\text { expert }\end{array}$ \\
\hline 1 & $\begin{array}{c}\text { The sum of ranks is } \\
\text { less than 7 points }\end{array}$ & $\begin{array}{c}\text { In the area AA\&SOA } \\
\text { professional competences are } \\
\text { created at a low level }\end{array}$ \\
\hline 2 & $\begin{array}{c}\text { The sum of ranks is } \\
\text { from } 8 \text { to } 14 \text { points }\end{array}$ & $\begin{array}{c}\text { In the area AA\&SOA } \\
\text { professional competences are } \\
\text { created at the medium level }\end{array}$ \\
\hline 3 & $\begin{array}{c}\text { The sum of ranks is } \\
\text { from } 15 \text { to } 37 \text { points }\end{array}$ & $\begin{array}{c}\text { In the area AA\&SOA } \\
\text { professional competences are } \\
\text { created at the basic level }\end{array}$ \\
\hline 4 & $\begin{array}{c}\text { The sum of ranks is } \\
\text { more } 37 \text { points }\end{array}$ & $\begin{array}{c}\text { In the area AA\&SOA } \\
\text { professional competences are } \\
\text { created at the high level }\end{array}$ \\
\hline
\end{tabular}

Determination of the level of competence of bachelor's degree in $\mathrm{BI}$ in the field of business activity

The requirements of the FSES HE for bachelors of BI and detailed details of them in the field of business activity (BA) are presented in Table 25.

Table 25

List of professional competencies of the bachelors of $\mathrm{BI}$ in the field of business activity

\begin{tabular}{|c|c|c|}
\hline $\begin{array}{l}\text { The list of the competences } \\
\text { regulated by FSES HE in the } \\
\text { field of BA }\end{array}$ & The graduate shows: & $\begin{array}{l}\text { Appointed } \\
\text { ranks }\end{array}$ \\
\hline \multirow{4}{*}{$\begin{array}{l}\text { PC-21: knowledge of the } \\
\text { fundamentals of pricing in } \\
\text { construction and housing } \\
\text { and utilities }\end{array}$} & $\begin{array}{l}\text { Knowledge of the fundamentals of pricing in construction and housing and } \\
\text { utilities at a low level }\end{array}$ & 1 \\
\hline & At the medium level & 2 \\
\hline & At the basic level & 3 \\
\hline & At the high level & 4 \\
\hline \multirow{4}{*}{$\begin{array}{l}\text { PC-21: knowledge of the ba- } \\
\text { sics of budgetary rationing in } \\
\text { construction and housing } \\
\text { and utilities }\end{array}$} & $\begin{array}{l}\text { Knowledge of the basics of budgetary rationing in construction and utilities at } \\
\text { a low level }\end{array}$ & 5 \\
\hline & At the medium level & 6 \\
\hline & At the basic level & 7 \\
\hline & At the high level & 8 \\
\hline \multirow{4}{*}{$\begin{array}{l}\text { PC-21: able to develop mea- } \\
\text { sures to increase the technical } \\
\text { and economic efficiency of } \\
\text { construction organizations } \\
\text { and housing and communal } \\
\text { services organizations }\end{array}$} & $\begin{array}{l}\text { The ability to develop measures to increase the technical and economic ef- } \\
\text { ficiency of construction organizations and housing and communal services } \\
\text { organizations at a low level }\end{array}$ & 1 \\
\hline & At the medium level & 2 \\
\hline & At the basic level & 3 \\
\hline & At the high level & 4 \\
\hline \multirow{4}{*}{$\begin{array}{l}\text { PC-22: the ability to develop } \\
\text { measures to increase the in- } \\
\text { vestment attractiveness of } \\
\text { construction sites }\end{array}$} & $\begin{array}{l}\text { The ability to develop measures to increase the investment attractiveness of } \\
\text { construction sites at a low level }\end{array}$ & 1 \\
\hline & At the medium level & 2 \\
\hline & At the basic level & 3 \\
\hline & At the high level & 4 \\
\hline \multirow{4}{*}{$\begin{array}{l}\text { PC-22: the ability to de- } \\
\text { velop measures to increase } \\
\text { the investment attractiveness } \\
\text { of housing and communal } \\
\text { services }\end{array}$} & $\begin{array}{l}\text { The ability to develop measures to increase the investment attractiveness of } \\
\text { housing and communal services at a low level }\end{array}$ & 1 \\
\hline & At the medium level & 2 \\
\hline & At the basic level & 3 \\
\hline & At the high level & 4 \\
\hline
\end{tabular}


STEP 1. We describe the pedagogical process of forming the competences of BI bachelors in the field of business activity with the help of attributes and the corresponding features. The results of this step are presented in the left and middle columns of Table 25.

STEP 2. Assign attributes of the attributes of the process which is being studied to the ranks. The results of this step are shown in the right column in Table 25.

Let us write down the values of the assigned ranks in Table 26.

Table 26

Values of the assigned ranks to the attributes of the process of forming the competencies of the BI bachelors in the field of business activity

\begin{tabular}{|c|c|c|c|c|c|c|c|c|}
\hline $\begin{array}{c}\text { No. } \\
\text { attribute } \\
\text { BA }\end{array}$ & \multicolumn{10}{|c|}{ Appointed ranks } \\
\hline 1 & 1 & 2 & 3 & 4 & 5 & 6 & 7 & 8 \\
\hline 2 & 1 & 2 & 3 & 4 & & & & \\
\hline 3 & 1 & 2 & 3 & 4 & & & & \\
\hline 4 & 1 & 2 & 3 & 4 & & & & \\
\hline
\end{tabular}

STEP 3. We perform the procedure for standardizing the ranks, the results of which are presented in Table 27.

Table 27

Values of Standardized ranks on the basis of attributes of the process of forming the competencies of the BI bachelors in the field of business activity

\begin{tabular}{|c|c|c|c|c|c|c|c|c|}
\hline $\begin{array}{l}\text { No. } \\
\text { attribute }\end{array}$ & $\Xi$ & & & indard & zed rar & & & \\
\hline 1 & 1 & 2 & 3 & 4 & 5 & 6 & 7 & 8 \\
\hline 2 & 1 & 0.5 & 0.5 & 0.5 & 0.5 & 0.5 & 0.5 & 4 \\
\hline 3 & 1 & 0.5 & 0.5 & 0.5 & 0.5 & 0.5 & 0.5 & 4 \\
\hline 4 & 1 & 0.5 & 0.5 & 0.5 & 0.5 & 0.5 & 0.5 & 4 \\
\hline Av.val. & 1 & 0.875 & 1.125 & 1.375 & 1.625 & 1.875 & 2.125 & 5 \\
\hline
\end{tabular}

As a result of the standardization of ranks, we obtained the tabulated function given in Table 28.

Table 28

Table valued function for determining level of formation of professional competences of bachelors of $B I$ in the field of business activity

\begin{tabular}{|c|c|c|c|c|c|c|c|c|}
\hline$X$ & 1 & 2 & 3 & 4 & 5 & 6 & 7 & 8 \\
\hline$Y$ & 1 & 0.875 & 1.125 & 1.375 & 1.625 & 1.875 & 2.125 & 5 \\
\hline
\end{tabular}

STEP 4. Construct a graph of this function on the interval [1, 8], (Fig. 5).

It follows from the graph in Fig. 5 that the interval $[1,8]$ is divided by boundary points 2,3 and 7 into 4 regions. The result of the recalculation of the boundary points to determine the estimated intervals is shown in Table 29.

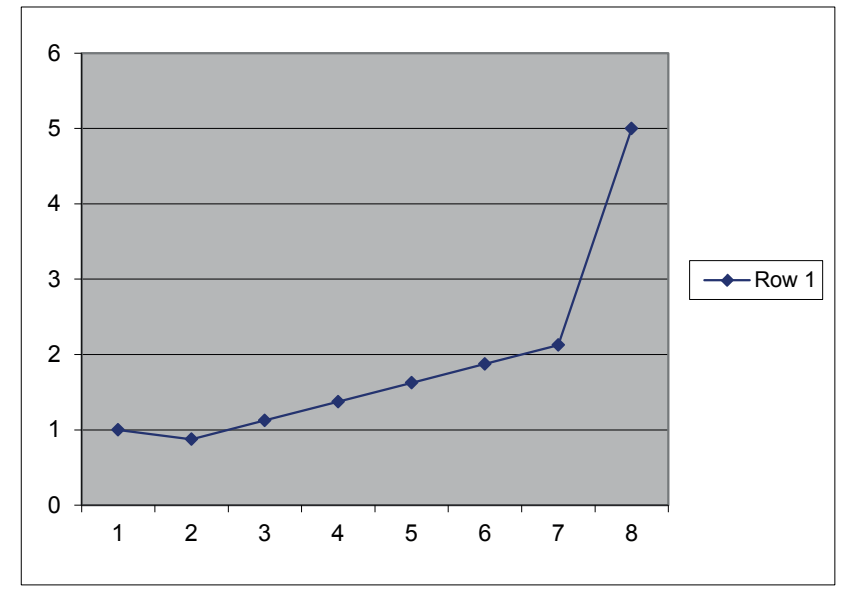

Fig. 5. The graph of the change in the average values of ranks when determining the level of competence of BI bachelor in the field of entrepreneurial activity

Table 29

Results of conversion of boundary points values in the evaluation intervals when determining the level of BI bachelor competence in the field of business activity

\begin{tabular}{|c|c|c|c|}
\hline $\begin{array}{c}\text { Values } \\
\text { boundary } \\
\text { ranks }\end{array}$ & $\begin{array}{c}\text { \% of values } \\
\text { boundary ranks } \\
\text { from the maxi- } \\
\text { mum quantity of } \\
\text { ranks }(8)\end{array}$ & $\begin{array}{c}\text { Sum of ranks, } \\
\text { corresponding } \\
\text { to border points } \\
\text { from the sum of } \\
\text { the maximum } \\
\text { ranks }(20)\end{array}$ & $\begin{array}{c}\text { Estimated } \\
\text { Interval }\end{array}$ \\
\hline 2 & 25 & 5 & $1 \leqslant \Sigma \leqslant 5$ \\
\hline 3 & 37 & 8 & $6 \leqslant \Sigma \leqslant 8$ \\
\hline 7 & 87 & 17 & $9 \leqslant \Sigma \leqslant 17$ \\
\hline
\end{tabular}

Now it is possible to formulate the final evaluation intervals for determining the level of competence of bachelors of $\mathrm{BI}$ in the field of business activity, which are presented in Table 30.

Table 30

Levels of competency formation of bachelors of BI in the field of business activity

\begin{tabular}{|c|c|c|}
\hline No. & Sum of ranks & Recommendations of the expert \\
\hline 1 & $\begin{array}{c}\text { The sum of ranks is } \\
\text { less than 5 points }\end{array}$ & $\begin{array}{c}\text { In the area BA professional } \\
\text { competences are created at a } \\
\text { low level }\end{array}$ \\
\hline 2 & $\begin{array}{c}\text { The sum of ranks is } \\
\text { from 6 to 8 points }\end{array}$ & $\begin{array}{c}\text { In the area BA professional } \\
\text { competences are created at the } \\
\text { medium level }\end{array}$ \\
\hline 3 & $\begin{array}{c}\text { The sum of ranks is } \\
\text { from } 9 \text { to } 17 \text { points }\end{array}$ & $\begin{array}{c}\text { In the area BA professional } \\
\text { competences are created at the } \\
\text { basic level }\end{array}$ \\
\hline 4 & $\begin{array}{c}\text { The sum of ranks is } \\
\text { more 17 points }\end{array}$ & $\begin{array}{c}\text { In the area BA professional } \\
\text { competences are created at the } \\
\text { high level }\end{array}$ \\
\hline
\end{tabular}

The application of the algorithm of the well-known mathematical method for standardizing ranks made it 
possible to calculate the estimated intervals for determining the levels of the formation of professional competencies regulated by the FSES HE in the direction of "Construction" training, for future bachelors-builders, namely in the prospecting and design activities, production and technological and production management activity, experimental and research activities, assembly and adjustment and service and operational activities and business activity.

Practical application of the developed mathematical model assumes the automation of the process of assessing the level of the formation of professional competence in a particular field of activity through the implementation in the form of an interactive software module and the development of special educational, methodological and control materials that allow the future bachelor-builder to demonstrate theoretical knowledge and skills, and practical experience in the research areas.

\section{References}

1. Bespal'ko V. P. Opyt razrabotki kriteriia kachestva usvoeniia znanii uchashchimisia [Experience of development of criterion of quality of assimilation of knowledge pupils]. Moscow, Publishing house of psychological social institute, 1969. 26 p. (In Russ.).

2. Bloom B.S. Taxonomy of educational objectives: classification of educational coal. New York, David McKay Publ., 1956. $207 \mathrm{p}$.

3. Zimniaia I.A. Kompetentnostnyi podkhod. Kakovo ego mesto $\mathrm{v}$ sisteme sovremennykh podkhodov $\mathrm{k}$ problemam obrazovaniia? (teoretiko-metodologicheskii aspekt) [Competence-based approach. What its place in the system of modern approaches to education problems? (theoretical and methodological aspect)]. Vysshee obrazovanie segodnia: reformy, novovvedeniia, opyt- The Higher Education Today: reforms, innovations, experience, 2006, no. 8, pp. 20-26. (In Russ.).

4. Literaturnaia entsiklopediia terminov i poniatii [Literary encyclopedia of terms and concepts]. Moscow, NPK "Intelvak" Publ., 2001. 1600 p. (In Russ.).
5. Mironova L. I. Metody analiza matematicheskikh modelei innovatsionnykh protsessov v sfere obrazovaniia [Methods of the analysis of mathematical models of innovative processes in education]. Trudy Instituta sistemnogo analiza RAN. Dinamika neodnorodnykh sistem - Works of Institute of the system analysis of RAS. Dynamics non-uniform system, 2010, vol. 49 (1), pp. 237-244. (In Russ.).

6. Mironova L. I. Primenenie matematicheskikh metodov v pedagogicheskikh issledovaniiakh [Application of mathematical methods in the pedagogical researches]. Vysshee obrazovanie segodnia - The Higher Education Today, 2010, no. 9, pp. 85-91. (In Russ.).

7. Mironova L. I. Examination in the pedagogical researches. Saarbrücken, LAP Lambert Academic Publishing, 2011. 97 p.

8. Novikova T. G. Examination in modern innovative practice. In: Innovative processes in education: theory and practice: collection of scientific articles. Moscow, 2001. $64 \mathrm{p}$.

9. Ozhegov S. I., Shvedova N. Iu. Tolkovyi slovar' russkogo iazyka: 80000 slov $i$ frazeologicheskikh vyrazhenii [Explanatory dictionary of Russian: 80000 words and phraseological expressions]. Moscow, Azbukovnik Publ., 2004. 1025 p. (In Russ.).

10. Plokhinskii N.A. Biometriia [Biometrics]. Moscow, Publishing house of Mos. State University, 1970. 368 p. (In Russ.).

11. Robert I. V. Sovremennye informatsionnye tekhnologii v obrazovanii: didakticheskie problemy, perspektivy ispol'zovaniia [Modern information technologies in education: didactic problems, prospects of use]. Moscow, Institute of informatization education of the Russian Academy of Education, 2010. 140 p. (In Russ.).

12. Sovremennyi slovar' inostrannykh slov [Modern dictionary of foreign words]. Moscow, Adelant Publ., 2014. 800 p. (In Russ.).

13. Federal'nyi gosudarstvennyi obrazovatel'nyi standart vysshego obrazovaniia, uroven' vysshego obrazovaniia: bakalavriat, napravlenie podgotovki Stroitel'stvo [Federal State educational standard of the higher education, level of the higher education: bachelor degree, direction of preparation 08.03.01 Construction]. Available at: http://fgosvo. ru/news/5/110 (In Russ.). 